Aronow, M.E. 26

Bandello, F. 16

Bastien, A. 21

Battaglia Parodi, M. 16

Berchicci, L. 16

Blasetti, N. 1

Folgar, A.M. 21

Iacono, P. 16

Kuhn, F. 21, 32

La Spina, C. 16

Loewenstein, A. 11
Moviglia, G.A. 1

Pabon, S. 26

Pelayes, D.E. 1, 21, 32

Rosenfeld, P.J. 6

Singh, A.D. 26

Takahashi, W. 21

Teixeira, S. 32

Vinicius, P.N. 21

Yehoshua, Z. 6

Zarate, J.O. 1, 21

\title{
Subject Index Vol. 48, Suppl. 1, 2012
}

Adult mesenchymal stem cells 1

Aflibercept 26

Age-related macular degeneration 11

Anti-vascular endothelial growth factor 16

Bevacizumab 16, 26

Chorioretinectomy 32

Choroidal neovascularization 6,11

Diabetic macular edema 16

Drusen 6

ForeseeHome 11

Geographic atrophy 6

Heavy brilliant blue G 21

Immunohistochemistry 21
Internal limiting membrane 21

Maculopathy 26

Pegaptanib 16

Preferential hyperacuity perimetry 11

Progression 6

Proliferative vitreoretinopathy 32

Radiation 26

Ranibizumab 16, 26

Retinal progenitor cells 1

Spectral domain optical coherence tomography 6

Stem cells 1

Trauma 32

VEGF Trap-Eye 16 